\title{
Hospitality in Islam as Based on Cornille's Conditions for Constructive Interreligious Dialogue
}

\author{
Adis Duderija
}

P R E C I S

This essay employs Catherine Cornille's conditions for a constructive interreligious dialogue theoretical framework with reference to the Islamic tradition as exemplified by the work of Reza Shah-Kazemi, a contemporary proponent of Islamic mysticism and the Islamic branch of religio perennialis. More specifically, it demonstrates how Cornille's "commitment," "interconnection," and "hospitality" conditions for constructive interreligious dialogue are very present in the Islamic tradition.

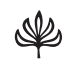

\section{Cornille's Conditions for Constructive Interreligious Dialogue}

atherine Cornille, in her recent theorizing on conditions under which
constructive interreligious dialogue can take place with specific refer-
ence to the teachings and practices of religious traditions, identified five
major factors that are said to play an important role in this regard. They in-
clude epistemological humility, commitment to a particular religious tradi-
tion, and recognition of their interconnection, empathy, and hospitality.
${ }^{1}$ See Catherine Cornille, "Conditions for Inter-Religious Dialogue," in Catherine
Cornille, ed., The Wiley-Blackwell Companion to Inter-Religious Dialogue, Blackwell Com-
panions to Religion (Oxford, U.K., and Malden, MA: Wiley-Blackwell, 2013), pp. $20-33$.
Also see Catherine Cornille, The Im-Possibility of Interreligious Dialogue (New York: Cross-
road/Herder \& Herder, 20o8). Cornille is one of the leading contemporary theoreticians
of interreligious dialogue and has published extensively in the field. 
By epistemic humility Cornille meant a process of "recognition of the very possibility of change or growth within one's own tradition," ${ }^{2}$ which presupposes a particular understanding of the nature of and approach to ultimate truth, namely, the inevitability of its "perspectivity" and thus humbleness and humility with respect to one's religious tradition's ability to grasp it completely and objectively. Humility, she argued further, can apply to the realm of doctrines, ethical systems, or rituals. Moreover, it can express itself in different ways, such as in the belief in "the relativity of all historical and cultural expression and/or in terms of a progression toward final clarity and understanding at some future point in time," both of which, in turn, assume that understanding of truth's fullness or completeness is nonabsolute and nonfinal. ${ }^{3}$ Additionally, Cornille remarked that integrating or recognizing epistemological humility necessitates a change in religious selfunderstanding for most religious traditions because of the self-confidence of their practitioners (and/or sacred texts associated with them) in claiming to have attained a definite and full truth.

Cornille recognized that "[s] ome religions do have ready resources for recognizing the limits of their claims to absolute and final truth." 4 Interestingly, she did not mention Islam as being one of them, which is one of the main reasons for my writing this essay. ${ }^{5}$ Cornille also highlighted that, in general, mystical interpretations of religious traditions are a fertile ground for recognition and expression of epistemological humility because they insist on the idea of the radical transcendence of ultimate reality and the human's utter inability to fully comprehend or grasp it. ${ }^{6}$ In the third section of this essay, I aim to demonstrate this with reference to a major contemporary proponent of Islamic mysticism and perennial philosophy, Reza Shah-Kazemi.

The second condition necessary for constructive religious dialogue identified by Cornille is commitment. By this she referred to the idea that one cannot have constructive dialogue unless one is committed to a certain religious tradition, because it is on the basis of this criterion that one is

\footnotetext{
${ }^{2}$ Cornille, "Conditions for Inter-Religious Dialogue," p. 21.

${ }^{3}$ Ibid.

${ }^{4}$ Ibid., p. 22.

${ }^{5}$ All of her examples are from either Mahayana Buddhist or Christian traditions.

${ }^{6}$ See Cornille, “Conditions for Inter-Religious Dialogue,” p. 22.
} 
able to delineate between "a purely personal exploration of the teachings of different religious traditions for spiritual enrichment" and the one that is based on one's adopting a position of a spokesperson or representative of a particular tradition by dialoguing from the perspective of "submitting one's judgment to" it. ${ }^{7}$ This idea of being a spokesperson for one's religious tradition is significant in terms of constructive dialogue for two reasons. First, it instills confidence in the dialogue partner that the views expressed are not merely a matter of personal opinion but are reflective of the broader tradition she or he represents. Second, it is only by this means that religious traditions as a whole, rather than specific individuals, can undergo growth and change. In this context Cornille wrote: "It is true that serious interreligious dialogue takes place between individuals. But it is only in so far as those individuals are willing to engage their own traditions with the insights and experiences gained through dialogue that traditions are also likely to grow and change." 8

Furthermore, Cornille noted, this argument does not mean that the individual speaks on behalf of all the various denominations of the particular religion in question or that the individual concerned has to possess a comprehensive understanding of it. However, commitment to and the idea of representing a tradition in its particular manifestation is important, as it is "a place of return for those involved in dialogue," and, in its idealistic form, it serves as a point of reference or a node for disseminating the potential fruits of dialogue to co-believers who might not be engaged in it.

The third element identified by Cornille is interconnection, which is encapsulated by the idea that religions are interconnected or related to each other by having a common object of focus or study. In other words, it assumes that all religions or religious traditions are in one way or another related to one another. These interconnections, for example, can include the identification of same or similar existential questions and/or the belief in the existence of an Ultimate Reality in contrast to just a common mystical experience. ${ }^{10}$ Without the recognition of this element, constructive religious dialogue would not be possible. In her words:

\footnotetext{
${ }^{7}$ Ibid., p. 23.

${ }^{8}$ Ibid.

${ }^{9}$ Ibid., p. 24.

${ }^{10}$ See ibid., p. 25.
} 
The possibility of constructive inter-religious dialogue thus requires that every religious tradition involved develop a religious self-understanding in which (at least some of) the teachings of other religions are somehow related to or relevant for one's own religious conception of truth. As such, different religions will have different conceptions of how they are connected to other religious traditions. But it is through such various conceptions of interconnection that dialogue takes place. ${ }^{11}$

In the second section of this essay I shall address the issue of Islam's selfpositioning vis-à-vis the religious others, especially in relation to its Abrahamic cousins, Christianity and Judaism.

The fourth element, empathy, pertains to the requirement of conceptual and experiential understanding, to some degree, of the religious Other that could enable the Self "to stretch one's religious imagination beyond the categories of one's own religion and gain some understanding of, and resonance with, religious teachings and practices other than one's own." ${ }^{12}$ Hence, constructive dialogue requires empathy in terms of understanding - or what Cornille termed "affective resonance with the other," whose benefits pertain to a more profound understanding of the meaning of particular teachings and practices as well as acting as the actual basis for engaging in constructive dialogue in the first place. In this regard Cornille opined: "It is only insofar as one is able to resonate positively with particular beliefs and experiences in another religion that one will be disposed to entertain the possibility of integrating such teachings in one's own religion." ${ }^{13}$ Importantly, empathy for the religious Other can be engendered by means of direct involvement in his or her religious life. However, for empathy to take place, it is not necessary for the dialogue partner to empathize with all elements of religious belief or practice associated with the religious Other.

Finally, the last element identified by Cornille is hospitality, by which she meant a process whereby recognition of truth in another religious tradition and the ability to integrate that truth in one's own tradition takes place. She held that the hospitality element is the most critical or sole sufficient condition for constructive dialogue, since it integrates or presupposes the recognition of the other four conditions discussed. In her words: "This con-

\footnotetext{
${ }^{11}$ Ibid., p. 26.

${ }^{12}$ Ibid.

${ }^{13}$ Ibid., p. 27.
} 
dition may be seen to include or presuppose most of the other conditions for dialogue: the recognition of truth in another religion presupposes some humility about the truth of one's tradition, commitment to a tradition which exercises hospitality, a general sense of the interconnectedness between religions, and genuine understanding of the other."14 Importantly, Cornille stated that the quality of hospitality as conceptualized above does not necessarily entail "recognition of truth in all religions, or in every dimension of a particular religion," but merely certain aspects or dimensions of them/it. ${ }^{15}$

Having briefly described the main delineating features of Cornille's conditions for constructive interreligious dialogue, I offer a few general remarks regarding the nature and development of the relationship between the Muslim Self and the religious Other. I do this, first, to contextualize the discussion in the third section. Second, understanding this Muslim Selfreligious Other dynamic has important implications with respect to Cornille's second condition of interconnection.

\section{Contextualizing the Relationship between the Muslim Religious Self and the Religious Other}

In order to gain an accurate understanding of how the normative fountainheads of Islam approach the relationship between the Muslim Self and the religious Other, more needs to be said about the revelatory environment in which the revelation and the Prophet's embodiment of it took place as it relates to the question of Muslim confessional identity and that of the religious Other, especially in the Medinian period. ${ }^{16}$ This is so not only because it was primarily in Medina that Muhammad's message, and therefore the Muslim identity, became more "Self-conscious," but also because the Medinian model of prophetic and early Muslim community is considered by many Muslims one to be emulated in as many aspects as possible, including that of the relationship with the religious Other. This approach, furthermore, is warranted by the fact that even a cursory examination of qur'anic

\footnotetext{
${ }^{14}$ Ibid., p. 28.

${ }^{15}$ Ibid.

${ }^{16}$ In the Islamic tradition Muhammad's mission is usually divided into two phases, Meccan and Medinian. After ten years or so of preaching in Mecca, Muhammad was more or less forced into exile to Medina, where he spent the rest of his life, some twelve years or so, establishing a community of believers.
} 
content (and therefore the Prophet's legacy) was organically linked to this context, especially its dimension that relates to the relationship between Muslims and the religious Other.

Ze'ev Maghen, a noted scholar of the nature of interactions between Muslims and non-Muslims in early Islam, described the context and the dynamics behind the relationship between Muslims and their normative tradition and non-Muslims, in particular with what the Qur'an terms the communities of the People of the Book (ahl-kitab), in the following manner:

Islam's relationship with the People of the Book has had its ups and downs. The growing familiarity of the inhabitants of the Arabian Peninsula with the ideas, institutions and communities of the surrounding monotheisms, followed by the initial and increasingly intense encounters of the nascent Muslim umma with the same, bred the complex mixture of attitudes to Judaism, Christianity and Zoroastrianism discernable through the classical literature of the faith. The seminal texts and genres-Qur'ān, Hadìth, Tafsir, Sharh, and Fiqh-evince a multifaceted and pendulating posture vis-à-vis the religio-cultural "other" that partakes more of dialectic than dogma. ${ }^{17}$

Based on this analysis of Maghen, in addition to those of Yohanan Fried$\operatorname{mann}^{18}$ and Jacques Waardenburg, ${ }^{19}$ several general points need to be considered in order to understand the concept of the Muslim Self and the religious Other during the time of the Prophet as depicted in the Qur'an and the Prophet's embodiment of it.

First, as noted briefly above, the context behind the emergence of Prophet Muhammad's message in seventh-century Hijaz was such that it took place alongside other already-well-established religious communities, the most important of which, apart from Arabian pre-qur'anic beliefs, were Judaism,

\footnotetext{
${ }^{17}$ Ze'ev Maghen, “The Interaction between Islamic Law and Non-Muslims, Lakum Dinukum wa-li Dini," Islamic Law and Society, vol. 10, no. 3 (2003), pp. 267-268.

${ }^{18}$ See Yohanan Friedmann, Tolerance and Coercion in Islam: Interfaith Relations in the Muslim Tradition (Cambridge, U.K., and New York: Cambridge University Press, 2003).

${ }^{19}$ Jacques Waardenburg, Muslims and Others: Relations in Context, Religion and Reason 41 (Berlin and New York: Walter de Gruyter, 2003). Also see Jacques Waardenburg, "World Religions as Seen in the Light of Islam," in Alford T. Welch and Pierre Cachia, eds., Islam: Past Influence and Future Challenge (Edinburgh: Edinburgh University Press; Albany, NY: State University of New York Press, 1979), pp. 245-276.
} 
Hanifyya, and Christianity. The very fabric and nature of the message embodied in the Qur'an clearly depicts many of the events and attitudes of the Muslim community ${ }^{20}$ toward the non-Muslim Other ${ }^{21}$ and vice versa.

Second, it is essential to point out that the quranic attitude (and $\mathrm{Mu}$ hammad's praxis) toward the non-Muslim Other is highly contextual in nature and therefore ambivalent or context-dependent. ${ }^{22}$ Additionally, for the large part of the "formative period" of the Muslim community in Medina, the climate of conflict, friction, and hostility prevailed among Muslims, mushrikun, large Jewish tribes, Christians, ${ }^{23}$ and religious hypocrites ( $m u$ nafiqun), ${ }^{24}$ under which Muslims were constantly concerned about the sheer survival of their community, often expressing itself in a reactionary, antagonistic type of identity toward the religious Other.

W. Montgomery Watt described the circumstances and the motives behind the relationship between Muslims and non-Muslims, especially between the Prophet of Islam and Jews in Medina, as follows: “In Muhammad's first two years at Medina the Jews were the most dangerous critics of his claim to be a prophet, and the religious fervour of his followers, on which so much depended, was liable to be greatly reduced unless Jewish criticisms could be silenced or rendered impotent.... in so far as the Jews changed their attitude and ceased to be actively hostile, they were unmolested."25

${ }^{20}$ I.e., the mu'minin/mu'minun-the believers.

${ }^{21}$ I.e., mushrikun (polytheists), munafiqun (hypocrites), al-ins (humankind), and Ahl-Kitab (People of the Book or recipients of previous revelations, primarily Jews and Christians). For a lucid account of this issue, see both Fred Donner, "From Believers to Muslims: Confessional Self-Identity in the Early Islamic Community," al-Abhath, vols. 50-51 (2002-2003), pp. 9-53; and Maghen, "The Interaction between Islamic Law and Non-Muslims."

${ }^{22}$ This ambivalence and contextuality is also found in nonqur'anic elements of tradition as embodied in various reports documenting the Prophet's life and that of his community. On qur'anic ambivalence in relation to the "other," see Maghen, "The Interaction between Islamic Law and Non-Muslims,” p. 268.

${ }^{23}$ Christians in Medina were numerically few, and they had much less economic influence. Thus, the Qur'an's “complaints” about Christians pertain primarily to the area of dogma. For more, see Jane McAuliffe, Qur'anic Christians: An Analysis of Classical and Modern Exegesis (Cambridge, U.K.: Cambridge University Press, 1991).

${ }^{24}$ A group of people in Medina who, according to the Qur'an, only superficially and for their own self-interest became Muslims but in reality were on the side of enemies of the Muslim community.

${ }^{25}$ W. Montgomery Watt, Muhammad at Medina (Oxford, U.K.: At the Clarendon Press, 1956), p. 217. 
This is well attested by the qur'anic content itself. This context-dependency of the scriptures toward the view of the (religious) Other (and, therefore, by implication the religious Self) led Waardenburg to assert, "Looking back at the interaction of the new Islamic religious movement with the existing religious communities, we are struck by the importance of sociopolitical factors. ${ }^{26}$

Apart from the sociopolitical factors, religious ideas were also significant, since qur'anic progressive consolidation of Islamic religious identity is inextricably linked with the religious identity of others, notably Jews and Christians. ${ }^{27}$ The aspects of religious-identity continuity and commonality with other faiths ${ }^{28}$ in the Qur'an are intertwined with those of the emergence and emphasis on the Muslim identity's originality and distinctiveness. ${ }^{29}$ Thus, the religious aspects of and interactions between various religious communities in the qur'anic milieu led to the genesis of the construction of religious identity of Muslims and played a very important role in it.

For example, in his study of the question to what extent Prophet $\mathrm{Mu}$ hammad and quranic scripture emphasized confessional distinctiveness, Fred Donner averred that, scripturally (that is, based upon quranic evidence) and in early Islam, the community of Believers seems to have been originally conceptualized independent of confessional identities and that it was only later-apparently during the third quarter of the first century A.H., a full generation of or more after the founding of Muhammad's community-that membership in the community of Believers came to be seen as confessional identity in itself, when, to use a somewhat later formulation of religious terminology, being a Believer and Muslim meant that one could not also be a Christian, say, or a Jew. ${ }^{30}$ In other words, Donner adduced substantial evidence that it could be argued that quranically

\footnotetext{
${ }^{26}$ Waardenburg, Muslims and Others, p. 99.

${ }^{27}$ See Donner, "From Believers to Muslims"; and Kate Zebiri, Muslims and Christians_Face to Face (Oxford, U.K.: Oneworld, 1997).

${ }^{28}$ Such as belief in Allah (One, True God), previous Prophets, belief in the hereafter, Day of Judgment, etc.

${ }^{29}$ The latter trend was more prominent in the context of the Muslim Medinian community.

${ }^{30}$ See Donner, "From Believers to Muslims," pp. 17-24 and 28-34; also see Maghen, “The Interaction between Islamic Law and Non-Muslims,” pp. 268-269.
} 
(some) Jews and Christians qualify as mu'minun (believers) as well as muslimun (those who submit to God). ${ }^{31}$

Friedmann detected a similar ancient layer in the Islamic tradition during which the boundaries of the Muslim community had not been precisely delineated and according to which "the Jews and the Christians belonged to the community of Muhammad." ${ }^{2}$ This "ancient layer of tradition ... was in general more considerate toward the People of the Book than that which eventually became the established law." 33

Another trend significant in the "historicity" of the development of the Muslim religious Self was the gradual, ever-growing, religious selfconsciousness of the Prophet of Islam and his early community. While attempts to find common ground and syncretism occurred more frequently during the earlier periods of Muhammad's life, ${ }^{34}$ later periods increasingly stressed confessional and self-conscious Muslim identity. ${ }^{35}$

An additional point to be considered in relation to the question under examination is the qur'anic concept of a hanif/millat Ibrahim. ${ }^{36}$ Qur'anically, this belief system is presented as a primordial, monotheistic Urreligion based on the belief in One, True God as embodied by Abraham's message (Arabic, Ibrahim) — considered as the universal belief system and as potentially the final evolution in Muhammad's attitude toward the religious Self and the Other. ${ }^{37}$ It is, however, unclear whether the Prophet of Islam himself identified historical Islam "as the only or merely as one possible realization of the primordial religion, the hanifinga, on earth." ${ }^{38}$

Because of its significance for the interconnection element of Cornille's theoretical framework, it is worth citing at least one verse pertaining to the

${ }^{31}$ See Donner, "From Believers to Muslims," pp. 17-24 and 28-34.

${ }^{32}$ Friedmann, Tolerance and Coercion in Islam, p. 195.

${ }^{33}$ Ibid., p. 194; also see Donner, "From Believers to Muslims," p. 32.

${ }^{34}$ Such as, e.g., the importance of Jerusalem and the praxis of Muslims to turn to it in prayer.

${ }^{35} \mathrm{~A}$ case in point is the change of direction in prayer from Jerusalem to Makkah. Traditions reportedly going back to the Prophet, such as those found in Sahih Bukhari, e.g., largely stress the distinctiveness and uniqueness of Islamic religious identity.

${ }^{36}$ For more on this, see Edmund Beck, "Die Gestalt des Abraham am Wendepunkt der Entwicklung Muhammads: Analyse von S.2.118 (124)-135 (141)," Le Museon, vol. 65 (1952), pp. 73-94.

${ }^{37}$ See Waardenburg, Muslims and Others, pp. 87-94.

${ }^{38}$ Ibid., pp. 106-107; emphases in original. Also, qur'anic verses such as 5:48 seem to apply the existence of religious plurality as a manifestation of God's will. 
idea of Hanifyya as Urreligion of all submitters to God (Muslims) in full: "So [you believers], say, 'We believe in God and in what was sent down to us and what was sent down to Abraham, Ishmael, Isaac, Jacob, and the Tribes, and what was given to Moses, Jesus, and all the prophets by their Lord. We make no distinction between any of them, and we devote ourselves to Him'" (Qur'an 2:136). ${ }^{39}$ Other verses such as $40: 78^{40}$ and 13:7 $7^{41}$ stipulate that the God of the Qur'an sent numerous Prophets to humankind in history, some of whom might have taken shape in a number of religions we find today. ${ }^{42}$ These verses, in other words, are in accordance with the interconnection element of Cornille's framework for constructive interreligious dialogue by affirming the common origin-and, therefore, common object of focusof all revealed religions, which, in turn, can contribute to creating constructive conditions for interreligious dialogue.

In the post-revelatory times the major delineating feature that marked the relationship between the Muslim religious Self and the religious Other was the fact that Islam became an imperial faith — and Muslims belonged to the ruling elite. Hence, Muslims were in a position "to determine the nature of their relationship with the others in conformity with their world-view and in accordance with their beliefs." 43

In summary, it would be fair to conclude that the relationship between the Muslim religious Self and the religious Other was contextual and underwent a number of shifts and developments that are evident both in the Qur'an and in early Muslim history. ${ }^{44}$ Given the nature of the historical

${ }^{39}$ M. A. S. Abdel Haleem, tr., The Qur'an, Oxford World's Classics (Oxford, U.K., and New York: Oxford University Press, 2005), is used for qur'anic quotations herein.

40 "We have sent other messengers before you-some We have mentioned to you and some We have not-and no messenger could bring about a sign except with God's permission. When [the Day] God ordained comes, just judgments will be passed between them: there and then, those who followed falsehood will be lost."

41 "The disbelievers say, 'Why has no miracle been sent down to him from his Lord?' But you are only there to give warning: [earlier] communities each had their guide."

${ }^{42}$ Indeed, a tradition found in one of the major collections, Ibn Hanbal's Musnad, documenting the life and events surrounding Muhammad, stipulates that this number is in excess of 100,000 messengers and/or prophets of God.

${ }^{43}$ Friedmann, Tolerance and Coercion in Islam, p. 1.

${ }^{44}$ Friedmann summarized it as follows: "Islam formulated toward each community that it faced a particular attitude, which was shaped by the historical circumstances in which the encounter took place, and was influenced to a certain extent by the nature of the respective non-Muslim religious tradition" (ibid.). 
sources, the exact dating of these shifts cannot be ascertained definitely. ${ }^{45}$ The interconnection of all revealed religions features prominently in the Islamic tradition as we saw above. In what follows, we examine one example of hospitality in Islam as theorized by Cornille.

\section{Hospitality in the Islamic Tradition in Light of Cornille's Theoretical Framework: \\ The Case of Reza Shah-Kazemi's Qur'anic Religious Universalism}

When it comes to the question of the normative relationship between Muslim Self and religious Other, both exclusivist and inclusivist interpretations of the Islamic tradition exist. ${ }^{46}$ On the question of finding resources in the Islamic tradition in favor of hospitality, I agree with the following statement by Friedmann on how Muslims today can approach the question of the relationship between the Muslim Self and the religious Other: "Creating a personal system of values by choosing appropriate elements from one's religious tradition is legitimate for a believer and desirable for all, especially in view of the fact that the building blocks for a tolerant version of Islam are indeed available in the Muslim tradition if interpreted with this purpose in mind." ${ }^{47}$ Therefore, either affirming or not affirming hospitality in Islamic tradition is a process that inevitably involves the question of interpretation and, more specifically, interpretive assumptions and methodologies. ${ }^{48}$

Above we saw that, according to Cornille, hospitality to the truth in the religious tradition of the religious Other is the sole sufficient condition for constructive interreligious dialogue. A number of Muslim scholars on the basis of different hermeneutics and epistemological approaches have developed understandings of their tradition that are in full accord with the principle of hospitality as described by Cornille. In the contemporary context

\footnotetext{
${ }^{45}$ See ibid.

${ }^{46}$ See Adis Duderija, Constructing a Religiously Ideal "Believer" and "Woman" in Islam: Neo-Traditional Salafi and Progressive Muslims' Methods of Interpretation (New York: Palgrave Macmillan, 2011), especially chaps. 4 and 7.

${ }^{47}$ Friedmann, Tolerance and Coercion in Islam, p. 5 .

${ }^{48}$ See Duderija, Constructing a Religiously Ideal "Believer," especially chaps. 3 and 6.
} 
they include both Sunni and Shi'i Muslim scholars, such as Tariq Ramadan, ${ }^{49}$ Abdolkarim Soroush, ${ }^{50}$ and Reza Shah-Kazemi. ${ }^{51}$

Here, I will concentrate on one of these scholars whose approach, in my view, fits particularly well in the theoretical framework as developed by Cornille, namely, Shah-Kazemi. This is because Shah-Kazemi's scholarship is both heavily informed by pre-modern as well as modern Islamic religious universalism discourses and because his particular conceptualization of the "universalist" Islamic teachings also accommodates a mode of "exclusivism" or what he calls "particularism" as described below, which is more likely to resonate among the general Muslim audience. Hence, it has a greater potential of drawing more Muslims into constructive interreligious dialogue as theorized by Cornille.

Shah-Kazemi is a British Ismai' li, Shi'i Muslim scholar who specializes among others in Sufism and comparative mysticism. ${ }^{52}$ His arguments for religious universalism - and. hence, affirmative views on hospitality in Islam as theorized by Cornille-are very qur'anocentric ${ }^{53}$ and are further supported by the insights of towering classical Sufi figures such as Al-Rumi (d. 1273) and, in particular, Ibn 'Arabỉs (d. 1240) universal hermeneutics discussed briefly below. As a proponent of religio perennialis, Shah-Kazemi's approach is also informed by the major contemporary Muslim proponents of this philosophy, including scholars such as Frithjof Schuon, Martin Lings, René Guénon, and Seyyed Hossein Nasr as advocates of the idea of "Islam" as universal and primordial submission. Therefore, Shah-Kazemi's views on religious universalism are not peculiar only to the Isma'ili theology but can also be considered, in many ways, to be representative of the

\footnotetext{
${ }^{49}$ See Tariq Ramadan, The Quest for Meaning: Developing a Philosophy of Pluralism (London: Penguin, 2010).

${ }^{50}$ See Abdolkarim Soroush, The Expansion of Prophetic Experience: Essays on Historicity, Contingency, and Plurality in Religion (Leiden: Brill, 2009).

${ }^{51}$ See Reza Shah-Kazemi, "Beyond Polemics and Pluralism: The Universal Message of the Qur'an," in Mohammad Hassan Khalil, ed., Between Heaven and Hell: Islam, Salvation, and the Fate of Others (Oxford, U.K., and New York: Oxford University Press, 2013), pp. 87-105; and idem, The Other in the Light of the One: The Universality of the Qur'an and Interfaith Dialogue (London: Islamic Texts Society, 2006).

${ }^{52}$ See http://www.iis.ac.uk/view_person.asp?ID=135\&type=auth.

${ }^{53} \mathrm{He}$ held that the question of affirming religious pluralism does not in essence require any "elaborate interpretive strategy" (Shah-Kazemi, "Beyond Polemics and Pluralism," p. 90).
} 
broader Islamic tradition. As noted by Cornille above in the context of the commitment element of her theoretical framework, this is an important consideration as it ensures that Shah-Kazemi's views are not based purely on individual subjective opinion or restricted just to Isma'ili tradition.

His views on the question of what would come under the hospitality element of Cornille's theoretical framework on constructive interreligious dialogue are presented most systematically in his recent chapter, "Beyond Polemics and Pluralism." Asking how we can transcend absolutist polemics without falling into the pitfall of relativistic pluralism, which he considers to be the main question that his work attempts to answer, Shah-Kazemi wrote:

The argument I make here is that the universality of the Qur'an provides us with the most effective answer to this question. This presentation of the universal message of the Qur'an is based on the tradition of Sufi metaphysics, in particular the school of thought deriving from Ibn 'Arabī (d. 1240). It also benefits from the insights of the contemporary school of thought known as the "perennial philosophy," associated chiefly with the name of Frithjof Schuon (d. 1998), and the most important contemporary scholarly exponent of which is Seyyed Hossein Nasr. ${ }^{54}$

Shah-Kazemi distinguished between religious pluralism as advocated by scholars such as John Hick ${ }^{55}$ and religious universalism. The former for Shah-Kazemi, despite its wish to the contrary, excludes most practicing people of their own religious traditions, because it dismantles the unique elements of the various religious traditions to which these people adhere, such as the belief that their religion is the only true religion. For ShahKazemi the claim to uniqueness in the pluralist paradigm is presupposed to be equal to claims of superiority that are antithetical to religious pluralist philosophy. Religious universalism does not exclude the "exclusivist" (that is, in his terminology, "particular") interpretations, because it considers a particular as an embodiment of the universal. In other words, religious universalism is based upon a view that the particular is integrated into the universal, and "the universal [is] embodied within the particular." ${ }^{66}$ Put

\footnotetext{
${ }^{54}$ See ibid., p. 89 .

${ }^{55}$ See John Hick, An Interpretation of Religion: Human Responses to the Transcendent (New Haven, CT: Yale University Press, 1989).

${ }^{56}$ Shah-Kazemi, "Beyond Polemics and Pluralism," p. 92; also see Ramadan, The Questfor Meaning.
} 
differently, there is a dialectic and symbiotic relationship between universal and particular, and one cannot exist without the other. Such a view of religious universalism is very affirmative of a number of elements of Cornille's theoretical framework, especially its interconnection and hospitality dimensions, for reasons discussed above.

As noted above, Shah-Kazemi has grounded such a view of religious universalism in the Qur'an as well as in the teachings of Sufi metaphysics, especially as represented by the great Muslim mystic Ibn 'Arabì as a proponent of religious universalism par excellence. In relation to the Qur'an, Shah-Kazemi quoted a number of quranic verses in support of religious universalism, including:

They also say, 'No one will enter Paradise unless he is a Jew or a Christian.' This is their own wishful thinking. [Prophet], say, 'Produce your evidence, if you are telling the truth.' In fact, any who direct themselves wholly to God and do good will have their reward with their Lord: no fear for them, nor will they grieve. (Qur'an 2:111-112)

[A]nyone, male or female, who does good deeds and is a believer, will enter Paradise and will not be wronged by as much as the dip in a date stone. Who could be better in religion than those who direct themselves wholly to God, do good, and follow the religion of Abraham, who was true in faith? God took Abraham as a friend. (Qur'an 4:124-125)

The Messenger believes in what had been sent down to him from his Lord, as do the faithful. They all believe in God, His angels, His scriptures, and His messengers. 'We make no distinction between any of His messengers.' (Qur'an 2:285a)

The [Muslim] believers, the Jews, the Christians, and the Sabians-all those who believe in God and the Last Day and do good—will have their rewards with their Lord. No fear for them, nor will they grieve. (Qur'an 2:62)

We have assigned a law and a path to each of you. If God had so willed, He would have made you one community, but He wanted to test you through that which He has given you, race to do good: you will all return to God and He will make clear to you the matters you differed about. (Qur'an 5:48b)

In reference to 2:211-212 Shah-Kazemi argued that these qur'anic verses demonstrate "the spiritual sterility of polemics and the logical absurdity of 
religious chauvinism." 57 Instead, he formed the view that these verses clearly imply that heartfelt submission to God in a nonconfessional manner when accompanied by virtuous deeds as a consequence of the same is the foundation for legitimate hopes for salvation. ${ }^{58}$ Furthermore, Shah-Reza opined that this interpretation of the passage is corroborated by 4:124-125 and that on the basis of these verses "the Qur'an helps us overcome the limitations of religious exclusivism." ${ }^{59}$

In reference to an imagined Western interlocutor's question as to what a credo of a Muslim is, Shah-Kazemi cited 2:285 to make a point that the "belief in all revealed religions is stressed here as an integral and not merely optional aspect of Islamic faith." ${ }^{60}$ To the interlocutor's question as to who will attain salvation according to the Muslim faith, Shah-Kazemi replied with 2:62 and argued that this qur'anic verse does not intend to provide an exhaustive list of all religions/faiths whose adherents will be saved, but that the Qur'an's purpose is to lay down the essential, but not sufficient, prerequisites for salvation, which are again identified as being faith and virtue. Shah-Kazemi cited a hadith from the Prophet to argue that salvation of any human beings, including those who self-identify as followers of Prophet Muhammad, is also contingent upon God's mercy. ${ }^{61}$ With respect to the imaged interlocutor's question why there is diversity of faiths, Shah-Kazemi referred to 5:48, arguing that this diversity is divinely willed, not a result of the diversity of human responses to God. Therefore, members of different faith communities should compete in doing goodness. ${ }^{62}$

Shah-Kazemi's symbiotic and dialectical relationship between universal and particular as inspired by Ibn 'Arabī's universal hermeneutics is particularly evident in his interpretation of a seemingly exclusivist qur'anic verse: "True religion in God's eyes is Islam: [devotion to Him alone]" (3:19a). Shah-Kazemi argued that the word "al-islām" in this verse could be legitimately interpreted as having both a universalist, nonreified as well as a reified, particular meaning because: "One can see the particular religion not

\footnotetext{
${ }^{57}$ Shah-Kazemi, "Beyond Polemics and Pluralism," p. 87.

${ }^{58}$ See ibid.

${ }^{59}$ Ibid., p. 88.

${ }^{60}$ Ibid., p. 90.

${ }^{61}$ Ibid.

${ }^{62}$ Ibid., p. 91.
} 
just as an embodiment of the universal principle but also as a path leading to that essence of which it is a formal embodiment. The universal essence manifests in and as the particular form; it is not contradicted by it." ${ }_{3}$

To counter the claim that the above-cited "universalist" verses such as 2:62 have been abrogated by $3: 85,{ }^{64}$ Shah-Kazemi questioned the theory of abrogation itself ${ }^{65}$ as espoused by some classical Muslim scholars by citing the works of scholar al-Ṭabarī (d. 923) and the Shi'î commentator al-Ṭabarsī (d. 1153), both of whom rejected the idea that a qur'anic verse can be subject to abrogation. He also relied on the "nuanced" abrogation theory of Ibn 'Arabī, according to which abrogation by necessity implies neither nullification/invalidation nor the idea "that the religions 'superseded' by Islam are rendered inefficacious in salvific terms. ${ }^{66}$ Furthermore, by applying Ibn 'Arabī's universalist hermeneutic in relation to the specific issue of the abrogation of $2: 62$ by $3: 85$, Shah-Kazemi argued that this verse ought to allow for both universalist and exclusivist interpretations to be considered as correct "even at the price of paradox," since no human interpreter can even claim to disqualify an interpretation that is grounded in textual evidence in the form of literal meaning. ${ }^{67}$ Importantly, Shah-Kazemi added, in agreement with Ibn 'Arabī, it is neither necessary to believe in the exclusivist interpretation as being the only correct interpretation nor to put this belief into practice. ${ }^{68}$ Shah-Kazemi also argued that, when examined in light of $3: 84$, the universalist interpretation of $3: 85$ is more "satisfactory" than the exclusivist one. In this context he wrote:

\footnotetext{
${ }^{63}$ Ibid., p. 93.

64 "If anyone seeks a religion other than [islam] complete devotion to God, it will not be accepted from him: he will be one of the losers in the Hereafter."

${ }^{65}$ One feature of qur'anic classical exegesis or tafsir pertains to the question of resolution of potential inconsistencies in the legal rulings of the Qur'an. These were generally resolved by taking recourse to other qur'anic science referred to in the relevant literature as al-näsikh wa-mansükh (the abrogating and the abrogated) or asbäb al nuzul, the reports detailing the "occasions of revelation." These sciences, in turn, were based on the concept of tanjim, the idea of the gradual development in the details of the regulations introduced in the Qur'an over its revelatory period. See Andrew Rippin, “Tafsīr," in P. Bearman, Th. Bianquis, C. E. Bosworth, E. van Donzel, and W. P. Heinrichs, eds., Encyclopaedia of Islam, 2nd ed. (Brill Online, 2014).

${ }^{66}$ Shah-Kazemi, "Beyond Polemics and Pluralism," p. 94.

${ }^{67}$ Ibid., p. 95.

${ }^{68}$ Shah-Kazemi leaves this "put into practice" undefined.
} 
The particular and historical form of Islam is doubtless to be situated at a lower level than the universal and timeless essence, but the particular is not to be trivialized, marginalized, or invalidated by the universal. On the contrary, the particular is elevated and ennobled in the very measure that it is deemed to be an expression of the universal - the form becomes more, not less, essential to the extent that it is grasped as an embodiment of the essence and a vehicle leading to the essence. ${ }^{69}$

As noted above, for Shah-Kazemi religious universality, if and when expressed as particularity, does not a priori and in itself amount to the invalidation of the former. Furthermore, he argued that this universalityparticularity dynamic in the Qur'an is also evident in how what he called "the universal principle of divine ubiquity" as embodied in the qur'anic verse, "'Wherever you turn, there is His Face' (Q. 2:115b)," is given a specific expression in another verse, namely: "Turn your face in the direction of the Sacred Mosque: wherever you [believers] may be, turn your faces to it' (Q. 2:144b).”70

A further argument affirming "hospitality" in Islamic tradition as espoused by Shah-Kazemi is revealed in his response to the imagined interlocutor's question, "What do you believe?" He again employed the imagery and terminology of Ibn 'Arabī according to which all revealed religions are lights, and the religion of Muhammad is like the light of the sun among the light of the stars as the answer:

When the sun appears, the lights of the stars are hidden, and their lights are included in the light of the sun. Their being hidden is like the abrogation of the other revealed religions that takes place through Muhammad's revealed religion. Nevertheless, they do in fact exist, just as the existence of the light of the stars is actualized [muhaqqaq]. This explains why we have been required in our all-inclusive religion to have faith in the truth of all the messengers and all the revealed religions. They are not rendered null (bātil) by abrogation - that is the opinion of the ignorant. ${ }^{71}$

\footnotetext{
${ }^{69}$ Shah-Kazemi, "Beyond Polemics and Pluralism," p. 97; emphasis in original.

${ }^{70}$ Ibid., p. 102.

${ }^{71} \mathrm{Ibn}$ al-'Arabī, as quoted in William C. Chittick, Imaginal Worlds: Ibn āl-'Arabī and the Problem of Religious Diversity (Albany, NY: State University of New York Press, 1994), p. 125, citing III 153:12, which is chap. 339 of al-Futūhät al-makkiyya.
} 
In his commentary of Ibn 'Arabī's above quote, echoing the sentiments of Rousseau, ${ }^{72}$ Shah-Kazemi formed the view that Islamic law's legal protection of those who adhere to other pre-quranic religious traditions can only make sense if these religious traditions are recognized as containing salvific material that inaugurated them in the first place as affirmed by the Qur'an. Had it been otherwise, argued Shah-Kazemi further, this legal protection "would be at best paradoxical, at worst, illogical."

Importantly, he argued, "This combination of universalism and particularism permits those practicing Muslims who are aware of the presence of holiness, truth, beauty, and virtue in religions other than Islam to do justice to their perception or intuition or 'taste' of the religions of the Other, without compromising fidelity and commitment to their own religion." ${ }^{74}$ In this context he asserted:

If one wishes to define the universality of the message of the Qur'an in a manner that appeals not only to liberals, pluralists, and universalists, but also to the vast majority of practicing Muslims, together with their conservative representatives, one cannot afford to ignore or dismiss the principle and the power of religious exclusivism. If, on the contrary, one's universalism is predicated upon a truly inclusive perspective, one that includes even the exclusivist perspective, then instead of alienating the exoteric scholars of Islam, one has at least a better prospect of winning over some of them. One also has a realistic chance of changing the attitudes of those who adopt a harsh, intolerant attitude toward the non-Muslim Other, encouraging them to take up a more gentle, tolerant attitude toward adherents of faiths that are granted recognition in the Qur'an and must be accorded protection according to the Sharia. ${ }^{75}$

As noted above, this is an important facet of Shah-Kazemi's approach, since it fully resonates with Cornille's "commitment" dimension of conditions for constructive interreligious dialogue.

\footnotetext{
72 "It is impossible to live at peace with people whom one believes are damned. To love them would be to hate God who punishes them. They must absolutely be either brought into the faith or tormented" (Jean-Jacques Rousseau, On the Social Contract with Geneva Manuscript and Political Economy, ed. Roger D. Masters, tr. Judith R. Masters [New York: St. Martin's Press, 1978], p. 131).

${ }^{73}$ Shah-Kazemi, "Beyond Polemics and Pluralism," p. 95.

${ }^{74}$ Ibid., p. 98.

${ }^{75}$ Ibid., p. 101.
} 


\section{Conclusion}

Based on the above considerations, Shah-Kazemi has not restricted salvation only to confessional Muslims but emphasizes the importance of "heartfelt submission to God" in combination "with the practice of virtue in consequence of that submission" as the only criteria "upon which one can legitimately hope for that divine grace." ${ }^{76}$ For Shah-Kazemi, Islam-or, more specifically, the Qur'an-is universalist insofar as it embraces the symbiotic dialectic dynamic between the universal and the particular. Therefore, it does not exclude the particular from the universalist. This is also the reason why Islam for Shah-Kazemi is the best religion. As noted earlier this view of religious universalism in Islam, in addition to considerations presented with respect to the very emergence of the Muslim religious Self as described in the second section above, meets most if not all of the conditions for constructive interreligious dialogue eloquently theorized by Cornille.

Adis Duderija (Muslim) is a lecturer in Islam and society at Griffith University, Nathan, WA, Australia. In 2016, he taught and was a research associate in Islamic studies at the University of Melbourne. In 2012-16, he lectured in the Gender Studies Dept. of the University of Malaya in Malaysia. In 2012, he was also a visiting research fellow in the Centre for Interdisciplinary Studies of the University of Sarajevo. He holds a Bachelor of Physical and Health Education and a Diploma in Modern Languages (German major) from the University of Western Australia; a Graduate Diploma in Teaching from Edith Cowan University, Perth; and a Ph.D. (2010) from the School of Social and Cultural Studies, Centre for Muslim States and Societies, University of Western Australia. He is an Associate Editor of Palgrave's communications, gender, and philosophy and religion sections and of Mathal/Mashal Journal of Interdisciplinary Islamic and Judaic Studies, as well as serving on the advisory boards of Middle East Studies Journal Online, Journal of Qur'an and Hadith Studies (Jakarta), Islamic Rethink Journal, and Australian Journal of Islamic Studies. His books include The Imperatives of Progressive Islam (Routledge, 2017); Islamic Teachings on Contemporary Issues for Young Muslims (co-authored) (National Centre for Excellence in Islamic Studies, 2016); and Constructing Religiously Ideal "Believer" and "Muslim Woman" Concepts: NeoTraditional Salafi and Progressive Muslim Methods of Interpretation (Manahij), Palgrave Series in Islamic Theology, Law, and History (2011; translated into Arabic in

${ }^{76}$ Ibid., p. 87 , and see p. 91. 
2013). He edited for Palgrave: Maqasid Al Shari'ah and Contemporary Muslim Reformist Thought (2014) and The Sunna and Its Status in Islamic Law (2015). His several articles have appeared as book chapters and in professional journals and encyclopedias. He has presented papers in conferences on several continents. In Perth, he cofounded the interfaith Abrahamic Alliance, and he regularly contributes to Newageislam.com. 
Copyright of Journal of Ecumenical Studies is the property of University of Pennsylvania Press and its content may not be copied or emailed to multiple sites or posted to a listserv without the copyright holder's express written permission. However, users may print, download, or email articles for individual use. 